\title{
Human and other critical factors in organizational learning in the hotel industry: A contingency approach
}

Personas y otros factores críticos en el aprendizaje organizativo en la industria hotelera: un enfoque de contingencias

\section{María del Mar Alonso-Almeida}

Universidad Autónoma de Madrid, Facultad de Ciencias Económicas y Empresariales Departamento de Organización de Empresas, Carretera de Colmenar Viejo, 28049 Madrid, Spain, mar.alonso@uam.es

\section{Maria de la Soledad Celemín-Pedroche}

Universidad Autónoma de Madrid, Facultad de Ciencias Económicas y Empresariales, Departamento de Organización de Empresas, 28049 Madrid, Spain, marisol.celemin@uam.es

\section{Luis Rubio-Andrada}

Universidad Autónoma de Madrid, Facultad de Ciencias Económicas y Empresariales, Departamento de Economía Aplicada, 28049 Madrid, Spain, luis.rubio@uam.es

\section{José Miguel Rodríguez-Antón}

Universidad Autónoma de Madrid, Facultad de Ciencias Económicas y Empresariales, Departamento de Organización de Empresas, 28049 Madrid, Spain, josem.rodriguez@uam.es

\begin{abstract}
Organizational learning is instrumental to successful adaptation to today's changing environment. Research on the subject in the context of the hotel industry is scant, however. The present study surveyed 147 Spanish hotels to determine the extent to which they drew from internal and external drivers and cultural and technological enablers and the level of organizational learning attained. These hotels were also characterized by the contingency factors most relevant to the industry and, based on the results, grouped into four clearly distinct clusters. An analysis of the groupings confirmed statistically significant inter-cluster differences. The empirical evidence gathered suggests that while all the hotel establishments studied stressed organizational learning, individual features determined differences in how successfully it is implemented. The inter-cluster differences identified suggest that the valuation of organizational learning varies with hotel type and, therefore, different organizational learning strategies must be implemented to attain higher performance.
\end{abstract}

Keywords: Organizational learning, contingency factors, learning enablers, internal drivers, external.

\section{Resumen}

En la actualidad, el aprendizaje organizativo es clave para adaptarse con éxito al entorno cambiante. Sin embargo, la investigación previa de este tema aplicado a la industria hotelera es escasa. Por ello, este estudio busca identificar el alcance de los factores conductores de adquisición de conocimiento, tanto internos como externos; analizar la adopción de facilitadores culturales y tecnológicos, y determinar el nivel de aprendizaje organizativo alcanzado por 147 establecimientos hoteleros ubicados en España. Además, este trabajo caracteriza los establecimientos hoteleros atendiendo a los factores de contingencia más relevantes en el sector. Sobre la base de estos factores, se desarrolló un análisis cluster para identificar la existencia de distintos grupos, resultando cuatro grupos claramente diferenciados, estudiándose las diferentes características de cada uno de ellos. Los resultados son relevantes ya que proporcionan evidencia empírica de que, aunque todos los establecimientos hoteleros estudiados potencian el aprendizaje organizativo, sus características propias sugieren diferencias en su grado de desarrollo y, por tanto, en su efectividad.

Palabras clave: Aprendizaje organizativo, factores de contingencia, potenciadores del aprendizaje, factores conductores internos, factores conductores externos.

\section{Introduction}

In recent years, tourist industry companies have seen their marketplace change substantially in terms of demographics, consumer needs, technological progress and shrinking tourist budgets. In such an environment, acquiring outside information is essential for long-term survival (e.g. Kumar et al., 2008; Alonso-Almeida \& Bremser, 2013; Ghaderi et al., 2014; Thomas \& Wood, 2015; Fraj et al., 2015). Tourist companies must therefore strive to establish links with their surrounds to acquire and transfer new knowledge. Companies acquire information not only from their environs (March, 1991), but also pursue knowledge across organizational boundaries (Garvin, 1993).

Previous research on organizational learning has focused mainly on two areas: analysis of the importance of acquiring internal and external knowledge, and analysis of the factors that drive such learning. Very little has been published in the empirical literature on organizational learning in the hotel industry to date. What little there is has primarily addressed issues such as measurement of the empirical relationships among organizational learning, knowledge transfer, organizational experience and strategic alliances or mergers (Ingram \& Baum, 2001); the knowledge transfer elements that affect learning (Kyriakidou \& Gore, 2005); organizational learning, knowledge sharing and obstacles to learning (Yang \& Wan, 2004; Akin Aksu \& Özdemir, 2005; Scott \& Ding, 2008; lebra Aizpurúa et al., 2011); transformation processes that enable organizations to learn (Bayraktaroglu \& Kutanis, 2003); employee training and the working environment and their effect on learning (Jameson, 2000; Gjelsvik, 2002; Furunes, 2005); the role that managers should play vis-à-vis employees 
(Yang, 2004; Teare 2011); determination of whether individual learning can enhance organizational learning (Yang, 2004; Popescu et al., 2011); the relationship between organizational learning, the internet and organizational performance (MartínRojas et al., 2014); the role of learning orientation on organizational competitiveness and performance (Tajeddini, 2011; Fraj et al., 2015); the connection between organizational learning, innovation and customer value (Nasution et al., 2011); and learning orientation and innovation as determinants in the development of proactive environmental management (Fraj et al., 2013)

No study was found, however, that jointly analyzes the factors that favor organizational learning in the hotel industry and how they affect such learning.

Therefore, the present study pursues, first, to identify the scope of both external and in-house knowledge acquisition mechanisms. Secondly, it explores both the adoption of learning enabling factors and the learning processes implemented by hotel management. Lastly, it characterizes hotel establishments empirically in terms of the contingency factors most relevant to the hotel industry that favor organizational learning. This may, then, be regarded an innovative study in two respects. Firstly, it determines hotel establishment typologies in terms of the key factors for organizational learning. And secondly, it characterizes each group in accordance with the contingent variables discussed below.

The paper begins with a review of the literature to provide comprehensive background on the state of play of the following questions: a) the internal and external drivers that play an active role in knowledge acquisition; b) learning enablers; c) organizational learning models and d) contingency factors affecting the tourist industry. The research methodology deployed is subsequently described, followed by a detailed analysis and discussion of the results. Lastly, the conclusions drawn are summarized, the limitations to the present study listed and future lines of research anticipated.

\section{Review of the literature}

Scant initial consensus was observed in the papers reviewed on the actual definition of organizational learning (Crossan et al., 1999; Williams, 2001). The quantitative and qualitative leap in research on the subject was not reflected in the literature until the nineteen nineties. Garvin (1993), for instance, viewed organizational learning as a complex multidimensional process in which knowledge is acquired to improve entrepreneurial performance. Further studies conceptualizing organizational learning have been forthcoming more recently. In that vein, Bayraktaroglu \& Kutanis (2003) compared organizational learning to organizational memory. In keeping with the aforementioned definitions, in this paper organizational learning is meant to be a complex and dynamic process that includes the acquisition, assimilation, transformation and exploitation of information gathered inside or outside the organization, as well as knowledge creation, facilitated by a series of cultural and technological learning enablers. In the present study, learning models, processes supported by a series of enablers, lie at the base of organizational learning.

Building on that definition of organizational learning, the following sections deal in some depth with the three basic elements that constitute the model proposed in this paper (see Figure 1): (1) the external and internal drivers that favor knowledge acquisition, (2) the learning enablers that facilitate learning and (3) the organizational learning models that form the basis of the model. Lastly, the contingency factors affecting the tourist industry are analyzed.

\subsection{Knowledge acquisition: external and internal drivers}

To ensure survival, hotel companies need to capture and internalise both external and internal knowledge (Ruhanen, 2008). Previous studies show that large global hotel chains such as Ritz Carlton or Marriott International have considerable experience in the field of organizational learning, and that Spanish hotel chains and individual hotels are making great progress in this area (Morcillo et al., 2008; lebraAizpurúa et al, 2011; Popescu et al., 2011; Fraj et al., 2013; Martín-Rojas et al., 2014). In this paper external drivers are defined to mean agents and procedures outside the organization from which information is gathered and internal drivers to mean agents and procedures within the organization through which information is gathered.

The mechanisms for capturing information outside the company identified by previous research include networking with external agents such as suppliers, customers, other companies, industrial networks, research institutes, government, universities, financial institutions, local and foreign consultants and other stakeholders (Kumar et al., 2008) through activities, routines or methods; joint work with external agents (Jamal \& Getz, 1995); personalized services (Buhalis \& Law, 2008); and meetings (Celemín, 2011).

In internal learning, however, since hotels, like other types of companies, are made up of individuals and groups with varying interests, objectives, loyalties and values (Williams, 2001), senior management must encourage employees to share knowledge (Yang, 2007) and to develop problem-solving skills (Yang, 2008). Such internal knowledge may be acquired by a number of procedures, including learning from colleagues, experience, organizational understanding and the organizational repository (Ordóñez de Pablo, 2002); meetings (Donate, 2007); inter-departmental cooperation (EasterbySmith et al., 2000); and organizational routines (Yang, 2004).

\subsection{Learning enablers}

Organizations may use a series of factors to enable both internal and external organizational learning. Such enablers have been grouped under two headings, cultural and technological.

\subsubsection{Cultural enablers}

The literature addresses a wide range of cultural factors that affect organizational learning. The most influential of these factors include organizational culture (Donate, 2007), history of the organization (Schilling \& Kluge, 2008), alliances 
(Easterby-Smith et al., 2000; Ingram \& Baum, 2001), leadership (Rodríguez-Antón \& Trujillo, 2007), teamwork (RodríguezAntón \& Trujillo, 2007), innovation (Gairín, 1997), organizational structure (Rodríguez Antón \& Trujillo, 2007), human resource practices (Donate, 2007), organizational strategy (Appelbaum \& Goransson, 1997), values and attitudes (Rhodes et al., 2008), learning capacity (Huber, 1991), systems and procedures (Martínez, 2002), and know-how and skills (López \& López, 2001).

Other cultural enablers such as innovation (Orfila-Sintes et al., 2005), organizational structure (Rodríguez-Antón \& Trujillo, 2007; Kumar et al., 2008) and systems and procedures (Kumar et al., 2008) have also been analyzed in the tourist industry, but less extensively.

\subsubsection{Technological enablers}

Technology has likewise proven to be one of the key enabling dimensions in organizational learning (Racherlaa et al., 2008). A company's technological capacity may favor the accumulation of technical know-how and learning on the organizational scale (Kumar et al., 2008). That greater technological capacity entails access to new modes of communication that intensify interactivity in the tourist industry (Buhalis \& Law, 2008). Information and comunication technologies (ICTs) and in particular the Internet were adopted by the industry very early on, prompting changes both in companies' everyday operations and their relations with external agents (Rodríguez-Antón et al., 2008).

The present study distinguished between two categories of technologies which are linked to organizational learning: technologies that support in-house, i.e., inter-employee learning, and those that support external learning, i.e., with other stakeholders. The in-house technologies reviewed were internet connection (Rodríguez-Antón et al., 2008; Redoli et al., 2008; Ruíz-Molina et al., 2011; Sooraksa; 2012; Pham et al., 2013; Martín-Rojas et al., 2014); intranet (Ruíz-Molina et al., 2011); electronic mail and databases (Redoli et al., 2008); websites (Buhalis \& Law, 2008; Redoli et al., 2008; Ruíz-Molina et al., 2011); and property management system (PMS) software (Redoli et al., 2008), to name a few. The external technologies considered in this study, among others, were internet connection (Buhalis \& Law, 2008; Ruíz-Molina et al., 2011; Martín-Rojas et al., 2014), including virtual web communities 2.0 (Lim et al., 2011; Ruíz-Molina et al., 2011); extranet (Pablo Redondo, 2004); electronic mail (Ruíz-Molina et al., 2011); electronic databases (Buhalis \& Law, 2008; Redoli et al., 2008); websites (Buhalis \& Law, 2008; Redoli et al., 2008; Ruíz-Molina et al., 2011); customer relationship management (CRM) software (Buhalis \& Law, 2008; Redoli, 2008, Ruíz-Molina et al.,
2011); and customer relationship system (CRS) software (Buhalis \& Law, 2008; Ruíz-Molina et al., 2011).

\subsection{Organizational learning models}

The present study used two complementary models of organizational learning (one of which combines another two models). The first is the Sun \& Anderson (2008) model, a combination of the Crossan et al. (1999) 4l (intuition, interpretation, integration and institutionalization) and the Zahra \& George (2002) models. The Crossan 41 model lies within the strategic renewal framework. Intuition is the process whereby new ideas and visions develop, based on personal experience resident in the individual's subconscious (Sun \& Anderson, 2008); interpretation is the phase in which individuals draw cognitive maps of the domains or terrains where they operate and from which they mine data; integration is the process through which mutual inter-personal comprehension is reached and action is coordinated by consent; and lastly, institutionalization, the stage in which routine action is assured, is the process in which the organization capitalizes on its members' learning (Crossan et al., 1999). The Zahra \& George (2002) model is based on absorptive capacity, defined as the dynamic capacity to establish organizational routines and processes. According to these authors, this vision of an organization's absorptive capacity comprizes four stages: knowledge acquisition, assimilation, transformation and exploitation.

The second model used was the $\mathrm{SECl}$ (socialization, externalization, combination and internalization) organizational learning model proposed by Nonaka \& Takeuchi (1995). This model constitutes a comprehensive approach to knowledge creation based on a mix of tacit and explicit knowhow (Nonaka \& Takeuchi, 1995). Socialization is the process whereby tacit knowledge is conveyed by experience and idea sharing, in which the recipient attains expertise very close to the levels possessed by the conveyor (Kogut \& Zander, 1992). Externalization is the stage in which tacit understanding is transformed into explicit knowledge through articulation and transfer to comprehensible media (Nonaka \& Konno, 1998). Externalization takes place when the company formally sets out its rules of procedure or when it explicitly establishes its organizational objectives (Martínez, 2002). Combination is the process in which explicit knowledge is synthesized and transferred to a knowledge base (Nonaka \& Konno, 1998). Lastly, internalization is the stage in the knowledge spiral in which individuals' tacit knowledge is enlarged by assimilating the organization's explicit knowledge. Internalization calls for updating explicit know-how and converting new explicit into tacit knowledge (Nonaka \& Konno, 1998). These models are summarized in Figure 1. 
Figure 1 - Organizational learning processes

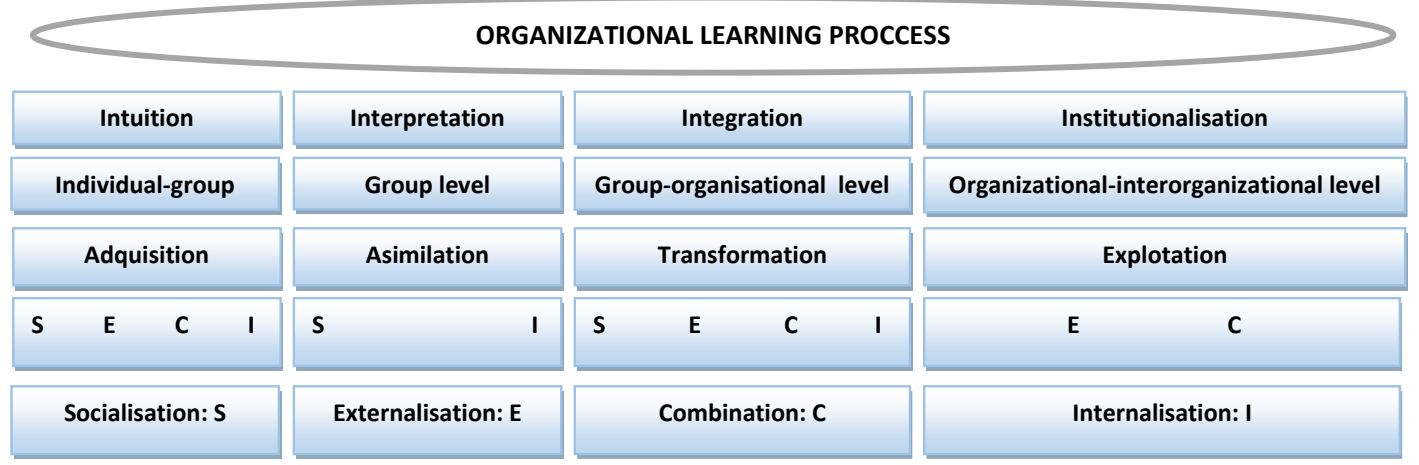

Source: authors' formulation based on the Nonaka \& Takeuchi (1995), Crossan et al. (1999), Zahra \& George (2002) and Sun \& Anderson (2008) models.

\subsection{Contingency factors affecting the tourist industry}

Since the mid-nineteen sixties, researchers have commonly acknowledged the existence of a series of factors which, while lying outside its bounds, nevertheless affect organizational design (e.g. Luthans, 1977; Minztberg, 1984 among others). In the contingency approach each company is viewed as a unique entity because each features distinguishing characteristics, denominated factors. These contingency factors, some external and others company-specific, affect its structure, organizational behavior and results.
A number of authors have analyzed the contingency factors most relevant to organizational behavior in the tourist industry (Álvarez-Gil et al., 2001; Garau \& Orfila-Sintes, 2008; AlonsoAlmeida \& Rodríguez-Antón, 2011; Rodríguez-Antón et al., 2012; Alonso-Almeida, 2012; Bremser et al., 2014; ParteEsteban \& Ferrer-Garcia, 2014).

According to their contributions, Figure 2 summarizes the design of the study built along the above theoretical lines, whose empirical validation is sought here.

Figure 2 - Working model proposed

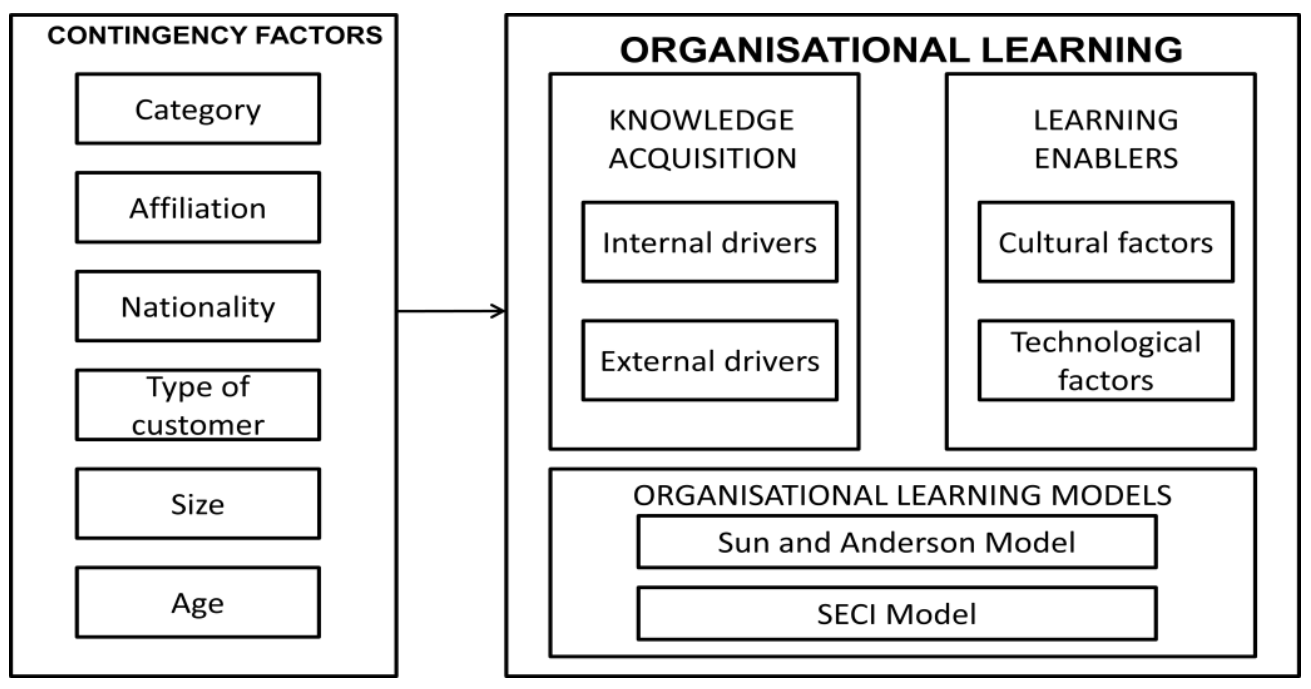

This model also ascertains the effect of contingency factors on organizational learning capacity in hotels, based on the factors listed below.

F1. Hotel category affects organizational learning capacity (Alonso-Almeida \& Rodríguez-Antón, 2011; Rodríguez-Antón et al., 2012).

F2: Affiliation with a chain affects hotels' organizational learning capacity (Álvarez-Gil et al., 2001; Garau \& OrfilaSintes, 2008; Rodríguez-Antón et al., 2012).

F3. Chain nationality affects organizational learning capacity (Rodríguez-Antón et al., 2012; Parte-Esteban \& Ferrer-Esteban, 2014).

F4: The type of customers catered to by hotels affects their organizational learning capacity (Álvarez-Gil et al., 2001;
Alonso-Almeida \& Rodríguez-Antón, 2011; Rodríguez-Antón et al., 2012; Alonso-Almeida, 2012).

F5. Age affects hotels' organizational learning capacity (Álvarez-Gil et al., 2001; Alonso-Almeida \& Rodríguez-Antón, 2011; Bremser et al., 2014).

F6. Size affects hotels' organizational learning capacity (Álvarez-Gil et al., 2001; Garau \& Orfila-Sintes, 2008; AlonsoAlmeida, 2012; Bremser et al., 2014).

\section{Methodology}

The present study was conducted in Spain, where tourism is one of the national economy's major and most dynamic industries, with a sizeable number of international tourist arrivals: 65 million in 2014 (FRONTUR, dic 2014), a total impact 
of \$US214 billion of Spain's GDP in 2014 and based on its direct, indirect, and induced GDP impact, Travel \& Tourism generated $15.2 \%$ of Spain's GDP in 2014 (WTTC, 2015). More specifically, it was confined to the region of Madrid, where the tourist industry accounts for $5.3 \%$ of the regional gross domestic product -GDP- (and $9.7 \%$ of nationwide tourist industry GDP) (IECM, 2012).
The population in this survey consisted of 370 three-, four- and five star hotels located in the region (in this five-point scale system, the greater the number of stars awarded the higher the quality of the establishment). The field work was conducted from April to August 2010, when information was gathered on 147 hotels, for a response rate of $39 \%$; the sampling error was estimated to be $6 \%$ at 95 per cent confidence. Sample characteristics are outlined in Table 1.

Table 1 - Specifications sheet for the study

\begin{tabular}{|c|c|c|c|}
\hline \multicolumn{4}{|c|}{ Hotel Characteristics } \\
\hline & & No. & Percentage \\
\hline \multirow{3}{*}{ Hotel category } & 3-star & 48 & 32.7 \\
\hline & 4-star & 84 & 57.1 \\
\hline & 5-star & 15 & 10.2 \\
\hline \multicolumn{2}{|l|}{ Total } & 147 & 100 \\
\hline \multirow{2}{*}{ Affiliation with a chain } & Yes & 111 & 75.5 \\
\hline & No & 36 & 24.5 \\
\hline \multicolumn{2}{|l|}{ Total } & 147 & 100 \\
\hline \multirow{2}{*}{ Type of chain } & National & 67 & 45.6 \\
\hline & International & 43 & 29.3 \\
\hline \multicolumn{2}{|l|}{ Total } & 110 & 74.8 \\
\hline \multirow{3}{*}{ Clientele type } & Vacation & 23 & 15.6 \\
\hline & Business & 107 & 72.8 \\
\hline & Vacation and business & 14 & 9.5 \\
\hline \multicolumn{2}{|l|}{ Total } & 144 & 98 \\
\hline \multirow{5}{*}{ Hotel age } & $<5$ years & 36 & 24.5 \\
\hline & 6 to 9 years & 32 & 21.8 \\
\hline & 10 to 19 years & 20 & 13.6 \\
\hline & 20 to 50 years & 42 & 28.6 \\
\hline & $>50$ & 16 & 10.9 \\
\hline \multicolumn{2}{|l|}{ Total } & 146 & 99.3 \\
\hline \multirow{5}{*}{ Number of rooms } & $<50$ & 21 & 14.3 \\
\hline & 50 to 90 & 45 & 30.6 \\
\hline & 100 to 199 & 50 & 34 \\
\hline & 200 to 299 & 20 & 13.6 \\
\hline & $>299$ & 11 & 7.5 \\
\hline \multicolumn{2}{|l|}{ Total } & 147 & 100 \\
\hline \multirow{4}{*}{ Total headcount } & $<10$ & 10 & 6.8 \\
\hline & 10 to 49 & 95 & 64.6 \\
\hline & 50 to 250 & 35 & 23.8 \\
\hline & $>250$ & 4 & 2.7 \\
\hline \multicolumn{2}{|l|}{ Total } & 144 & 98 \\
\hline
\end{tabular}

A survey was conducted. The survey was based on a structured questionnaire with a total of 78 five-point Likert scale questions based on the findings reported in the literature to obtain information on: 1) internal and external knowledge drivers; 2) cultural and technological learning enablers; 3 ) the organizational learning process itself; and 4) respondent and hotel characteristics. A total of 61 variables were measured.

A three-step procedure was implemented to validate the survey. First, a series of items described in the literature for each dimension studied were collected. A panel of four academic experts in the area was then asked to analyze and assess the full list of items compiled with a view to determining their validity as a measuring tool. Finally, a pretest was conducted that was then assessed by three senior managers: one in a three-, one in a four-, and one in a five-star hotel in the region of Madrid. The final questionnaire was drawn up based on their opinions, after which the survey was launched.

After the data was collected, the consistency and reliability of the questionnaire were ascertained by applying Cronbach's alpha. Once the sample was shown to be representative by cross-validation, principal components analysis (PCA) was performed and the first components in each block were used to conduct a cluster analysis. A contingency analysis was then 
run to determine the relationship between the clusters and certain hotel characteristics. Cross-validation, PCA, cluster analysis and contingency analysis are described more fully in the following section.

\section{Results}

\subsection{Cluster analysis}

Before proceeding to cluster analysis, the sample was checked for representativeness. The cross validation conducted to that end showed that the sample was stable and not dependent upon its own characteristics. No statistically significant differences between means were found in any of the analyzes. This was followed by a reliability and internal consistency analysis for each block of the survey, performed with Cronbach's alpha. Values of over 0.7 (see Cronbach, 1951) were obtained for all factors (Table 2).

With a view to reducing the number of variables, principal component analysis (PCA) was conducted in which the first principal component of each block was defined as its indicator, ensuring that it accounted for a suitable percentage of the total variability (Table 2 for more detailed information about the factorial loads for the first factor relative to each of the variables in each block, as well as the variance explained by each factor).
Lastly, as in previous studies (Mazzocchi, 2008), four-step clustering was applied, as follows: 1) the variables were initially selected in accordance with theoretical considerations; 2) hierarchical cluster analysis was conducted as per Ward's method; 3) k-means clustering was performed with the results of step 2; and 4) an ANOVA was run to verify the findings.

In fact, a cluster analysis was run using the seven principal components (Picón et al., 2005) defined (external agents, information capture by external agents, internal agents, information capture by internal agents, cultural enablers, technological enablers and organizational learning itself). Afterwards a Ward's hierarchical method was used. The four clusters that in a study of the dendogram were shown to reduce the Euclidean distance the most and smooth the segments most effectively were selected. The independent variable for this analysis was the four clusters defined and the dependent variables were the seven principal components.

The composition of the four clusters defined was as follows: the first comprized 59 hotels, the second 37 the third 33 and the fourth 18. The means and standard deviations for the main components in each cluster are given in Table 2. Since in this case the principal components are the object of the analysis, the means and standard deviations refer not to the original scale of 1 to 5 , but to standard scores obtained by subtracting the mean and dividing by the standard deviation.

Table 2 - Clusters and Factors

\begin{tabular}{|c|c|c|c|c|c|c|c|c|c|c|}
\hline \multirow{3}{*}{ Factor } & \multirow{3}{*}{$\begin{array}{l}\text { Cronbach's } \\
\text { alpha }\end{array}$} & \multirow{3}{*}{$\%$ variance } & \multicolumn{8}{|c|}{ Cluster } \\
\hline & & & \multicolumn{2}{|c|}{1} & \multicolumn{2}{|c|}{2} & \multicolumn{2}{|c|}{3} & \multicolumn{2}{|c|}{4} \\
\hline & & & Mean & Std dv. & Mean & Std dv. & Mean & Std dv. & Mean & Std dv. \\
\hline External agent indicator & 0.761 & 35.757 & 0.769 & 0.837 & -0.612 & 0.573 & -0.288 & 0.819 & -0.734 & 0.803 \\
\hline $\begin{array}{l}\text { Information capture from } \\
\text { external agent indicator }\end{array}$ & 0.805 & 56.348 & 0.833 & 0.684 & -0.355 & 0.714 & -0.425 & 0.708 & -1.220 & 0.605 \\
\hline Internal agent indicator & 0.773 & 60.824 & 0.575 & 0.672 & 0.087 & 0.900 & -0.294 & 0.628 & -1.522 & 0.897 \\
\hline $\begin{array}{l}\text { Information capture from } \\
\text { internal agent indicator }\end{array}$ & 0.840 & 62.457 & 0.759 & 0.443 & 0.154 & 0.536 & -0.526 & 0.641 & -1.840 & 0.606 \\
\hline Cultural enabler indicator & 0.849 & 45.112 & 0.228 & 0.618 & 0.692 & 0.857 & -0.913 & 0.806 & -0.497 & 1.186 \\
\hline ICT indicator & 0.956 & 50.375 & 0.456 & 0.764 & 0.138 & 0.826 & -0.183 & 0.750 & -1.444 & 1.029 \\
\hline $\begin{array}{l}\text { Organizational learning } \\
\text { indicator }\end{array}$ & 0.912 & 45.284 & 0.473 & 0.599 & 0.252 & 0.815 & -0.392 & 0.826 & -1.349 & 1.238 \\
\hline
\end{tabular}

Table 2 shows that in the first, respondents scored all the principal components at values substantially higher than the mean. Consequently, cluster 1 was denominated "Hotels that encourage organizational learning at all levels". In the second cluster, both the external agents and information capture from these agents scored below the mean, while the rest of the factors, particularly cultural factors, scored above the mean. Cluster 2 was therefore denominated "Hotels that encourage organizational learning internally". The third cluster had scores considerably lower than the mean in all items and in contrast to cluster 2, especially with respect to cultural factors. It was therefore denominated "Hotels that encourage organizational learning moderately". Lastly, the fourth cluster, showed the lowest scores for all components, with the exception of cultural enablers. Cluster 4 was consequently denominated "Hotels that encourage organizational learning only scantly". Since clusters simply establish groups whose values lie above or below the overall mean, the values in question revealed only the relative position of each hotel type or category, but offered no information on whether they favored learning or otherwise.

\subsection{Contingency analysis}

A contingency analysis was performed to determine the relationship between clusters and certain hotel characteristics. The main contingency analysis results are shown in Table 3. Thee results show that hotel characteristics affect their organizational learning capacity. 
Table 3 - Contingency analysis findings

\begin{tabular}{|c|c|c|c|c|c|}
\hline & & \multicolumn{4}{|c|}{ Cluster } \\
\hline & & 1 & 2 & 3 & 4 \\
\hline \multirow{3}{*}{$\begin{array}{l}\text { Hotel category (number of } \\
\text { stars) }\end{array}$} & 3 & $27.1 \%$ & $27.1 \%$ & $25.0 \%$ & $20.8 \%$ \\
\hline & 4 & $41.7 \%$ & $25.0 \%$ & $23.8 \%$ & $9.5 \%$ \\
\hline & 5 & $73.3 \%$ & $20.0 \%$ & $6.7 \%$ & $0.0 \%$ \\
\hline \multirow{2}{*}{ Is your hotel chain-affiliated? } & No & $25.0 \%$ & $25.0 \%$ & $27.8 \%$ & $22.2 \%$ \\
\hline & Yes & $45.0 \%$ & $25.2 \%$ & $20.7 \%$ & $9.0 \%$ \\
\hline \multirow{2}{*}{ Chain nationality } & National & $41.8 \%$ & $19.4 \%$ & $23.9 \%$ & $14.9 \%$ \\
\hline & International & $51.2 \%$ & $32.6 \%$ & $16.3 \%$ & $0.0 \%$ \\
\hline \multirow{3}{*}{$\begin{array}{l}\text { The hotel's clientele consists } \\
\text { primarily of }\end{array}$} & Vacationers & $30.4 \%$ & $26.1 \%$ & $34.8 \%$ & $8.7 \%$ \\
\hline & Business people & $43.9 \%$ & $23.4 \%$ & $20.6 \%$ & $12.1 \%$ \\
\hline & $\begin{array}{l}\text { Vacationers and business } \\
\text { people }\end{array}$ & $35.7 \%$ & $35.7 \%$ & $14.3 \%$ & $14.3 \%$ \\
\hline \multirow{5}{*}{ Hotel age (years) } & $<5$ & $38.9 \%$ & $27.8 \%$ & $22.2 \%$ & $11.1 \%$ \\
\hline & 6 to 9 & $46.9 \%$ & $18.8 \%$ & $18.8 \%$ & $15.6 \%$ \\
\hline & 10 to 19 & $35.0 \%$ & $35.0 \%$ & $20.0 \%$ & $10.0 \%$ \\
\hline & 20 to 50 & $35.7 \%$ & $21.4 \%$ & $31.0 \%$ & $11.9 \%$ \\
\hline & $>50$ & $50.0 \%$ & $25.0 \%$ & $12.5 \%$ & $12.5 \%$ \\
\hline \multirow{4}{*}{ Headcount (No. employees) } & $<10$ & $0.0 \%$ & $20.0 \%$ & $30.0 \%$ & $50.0 \%$ \\
\hline & 10 to 49 & $36.8 \%$ & $26.3 \%$ & $24.2 \%$ & $12.6 \%$ \\
\hline & 50 to 250 & $51.4 \%$ & $25.7 \%$ & $20.0 \%$ & $2.9 \%$ \\
\hline & $>250$ & $100.0 \%$ & $0.0 \%$ & $0.0 \%$ & $0.0 \%$ \\
\hline \multirow{5}{*}{ Number of rooms } & $<50$ & $19.05 \%$ & $23.81 \%$ & $28.57 \%$ & $28.57 \%$ \\
\hline & 50 to 99 & $35.56 \%$ & $35.56 \%$ & $17.78 \%$ & $11.11 \%$ \\
\hline & 100 to 199 & $46.00 \%$ & $18.00 \%$ & $22.00 \%$ & $14.00 \%$ \\
\hline & 200 to 299 & $45.00 \%$ & $30.00 \%$ & $25.00 \%$ & $0.00 \%$ \\
\hline & $>299$ & $63.64 \%$ & $9.09 \%$ & $27.27 \%$ & $0.00 \%$ \\
\hline
\end{tabular}

So, most (73.3 per cent) of the five-star hotels were classified in cluster 1 , i.e., hotels that favor organizational learning at all levels. Conversely, none of these highest category establishments was present in cluster 4, consisting of hotels that encourage organizational learning only scantly. Lastly, many more four-star hotels were found in cluster 1 than in cluster 4: 41.6 compared to 9.5 per cent (see Annex 1 and Table 3). These observations, which corroborate Factor 1 , are consistent with the results reported by Garau \& Orfila-Sintes (2008) and Rodríguez-Antón et al. (2012).

Affiliation with a hotel chain might also be conducive to organizational learning. Specifically, cluster analysis showed that hotels affiliated with a chain were classified primarily (45 per cent) in cluster 1 , whose elements encourage organizational learning at all levels. Chain hotels also fit a pattern similar to the luxury hotels, in that very few were found to "scantly encourage learning". In contrast, non-chain hotels were distributed nearly evenly across the four clusters (see Annex 2). This would confirm Factor 2, i.e., affiliation with a hotel chain is a determinant in the encouragement of organizational learning, as reported in the literature (Alonso-Almeida \& Rodríguez-Antón, 2011; RodríguezAntón et al., 2012; Garau \& Orfila-Sintes, 2008; Rodríguez-Antón et al., 2012).
Table 3, in turn, shows that international chains favor organizational learning more than national chains. A major share (83.8 per cent) of the hotels in the former group were observed to lie in clusters 1 and 2 , and none in cluster 4 , whereas a significant 38.8 per cent of hotels affiliated with national chains were classified in clusters 3 and 4 , even though a relative majority (41.8 per cent) were in cluster 1.

These findings, which would confirm Factor 3, although not reported in prior studies, suggest that foreign chains operating in Spain are more predisposed to organizational learning than their Spanish counterparts, perhaps as a result of having to compete on the international marketplace. Previous reseach (Rodríguez-Antón et al., 2012; Alonso-Almeida et al., 2013; Parte-Esteban \& Ferrer-García, 2014) has suggested that the management practices implemented by Spanish and foreign hotel chains differed due to differences in management culture.

In terms of type of clientele, 74.3 per cent of the respondent hotels were geared specifically to business customers, while 16.0 per cent engaged in vacation tourism and 9.7 per cent were mixed. Of the three types, business hotels proved to be most prone to favor organizational learning, with 43.9 per cent in cluster 1 (see Table 3). This may be because business customers, who tend to return to the same hotel more 
frequently than leisure time customers, attach particular importance to a hotel's ability to perceive and retain their likes and needs. And that is one of the outcomes of organizational learning. The hotels they patronise would therefore logically have a greater incentive to obtain such information.

These findings would confirm Factor 4 and complement the results of the studies conducted by Álvarez-Gil et al. (2001), Alonso-Almeida and Rodríguez-Antón (2011), Alonso-Almeida (2012) and Rodríguez-Antón et al. (2012), which identified differences in management practices depending on whether the hotel catered to business or tourist customers.

The findings for the variable hotel age, in turn, showed that 50.0 per cent of the oldest hotels (over 50 years old) were positioned in cluster 1 (see Table 3). These observations would confirm Factor 5, but differed from the results of an analysis of environmental measures conducted by Álvarez-Gil et al. (2001), which showed that hotel age affected the adoption of certain management practices, but in different ways depending on the decision to be made.

Lastly, all the hotels with more than 250 employees were positioned in cluster 1 , whereas all the hotels with fewer than 10 employees were distributed across clusters 2, 3 and 4, with none in cluster 1 (see Table 3). Most (63.6\%) of the largest hotels measured by number of rooms ( $>299$ rooms) were observed to lie in cluster 1 . By contrast, $57.1 \%$ of the hotels with fewer than 50 rooms were positioned in clusters 3 and 4 , i.e., less prone to organizational learning (see Table 3). These findings, which would support Factor 6, are consistent with the results published by Álvarez-Gil et al. (2001) and Garau \& Orfila-Sintes (2008), according to which larger hotels tend to be better equipped to adopt more advanced management practices than their smaller counterparts.

\section{Discussion, conclusions, limitations and future lines of research}

A number of the empirical findings of this study, which complement previous results, are of interest for the literature on organizational learning in the tourist industry.

Firstly, all the factors studied proved to be relevant to organizational learning in the hotel industry. The hotels in two of the clusters identified, clusters 1 (hotels that encourage learning at all levels) and 2 (hotels that encourage organizational learning internally), which accounted for the largest number of companies sampled, attached more than the average importance to the factors that determine collective learning capacity. The conclusion that can be drawn is that the present findings are in line with research conducted by Popper \& Lipshitz (2000), which showed that information capture from internal agents and the cultural and technological factors that constitute an organizational system are keys to the existence of organizational learning. Consequently, hotel companies need to make a special effort to encourage their employees (internal agents) to participate in these processes by drawing from both the company's organizational culture and all available technological tools.
The present study constitutes a new approach to analyzing the effect of contingency factors on organizational learning in the hotel industry. The inter-cluster differences identified suggest that while all hotels learn, learning intensity varies depending on their characteristics.

By category, five-star hotels, for instance, clearly attempt to learn as organizations. Three-star establishments, in contrast, are found in all four clusters and are not clearly geared to learning. Four-star hotels stand in an intermediate position. These results clearly indicate that the higher the hotel category and hence the more demanding the clientele, the more predisposed is the establishment to learning.

Hotels affiliated with chains, particularly international chains, are also more prone to pursuing joint learning and regarding the process as an essential component of company development. This can be attributed to their need to understand the tastes and needs of a widely varied clientele from different countries, further to the international scope of the hotel group with which they are affiliated. In keeping with these results, Ingram \& Baum (2001), who studied interorganizational learning in the context of chain affiliation, found that hotels that joined chains acquired survival advantages if the chains had accumulated experience that could be transferred to such adherents. This finding suggests that where learning is essential, such as in complex hotel structures, it is valued more highly.

The findings likewise revealed that hotels geared specifically to business customers are more likely to favor organizational learning-related factors than other types of hotels. Here the explanation may be that since business customers tend to be more demanding than vacationers, the hotel has no choice but to make an extra effort to discover their needs to offer a product or service that meets with their satisfaction.

Lastly, the oldest establishments and the ones with the largest number of rooms or employees are also more likely to favor organizational learning-related factors than other types of hotels. This may be because older hotels have longer experience in implementing organizational learning and that in large hotels, as in chains, size facilitates organizational learning by ensuring the financial feasibility of the respective technological enablers.

The present findings are nonetheless subject to a series of limitations. The first is that inasmuch as the survey was conducted in one region only, the results may not be representative of hotels located in others. Moreover, the information reflects the perceptions of only one respondent, a senior manager, per establishment. While executives are regarded as reliable sources of information in light of their experience and expertise, their opinions may not necessarily be wholly objective.

With a view to removing these constraints, future lines of research envisage extending the sample to other regions and conducting comparative analyzes. Future research would also seek the opinions of both front and back office employees. A third avenue would be to collect data from a cross-section of hotel employees in each cluster group to determine whether 
the present findings concur with employees' perceptions. The fourth avenue would consist of supplementing the qualitative research methodology with case studies and exploring the role of each contingency factor in organizational learning in greater depth. A fifth and last avenue would be to apply this approach to other service industries.

\section{References}

Akin Aksu, A. \& Özdemir, B. (2005). Individual learning and organization culture in learning organizations. Managerial Auditing Journal, 20(4), 422-441.

Alonso-Almeida, M., \& Bremser, K. (2013). Strategic responses of the Spanish hospitality sector to the financial crisis. International Journal of Hospitality Management, 32, 141-148.

Alonso-Almeida, M.M. \& Rodríguez-Antón, J.M. (2011). Organizational behavior and strategies in the adoption of certified management systems. an analysis of the Spanish hotel industry. Journal of Cleaner Production, 19(13), 1455-1463.

Alonso-Almeida, M. M. (2012). Water and waste management in the Moroccan tourism industry: The case of three women entrepreneurs. Women's Studies International Forum, 35(5), pp. 343-353.

Álvarez-Gil, M.J., Burgos, J. de. \& Céspedes, J.J. (2001). An analysis of environmental management, organizational context and performance of Spanish hotels. Omega, 29(6), 457-471.

Appelbaum, S.H. \& Goransson, L. (1997). Transformational and adaptative learning within the learning organization: A framework for research an application. The Learning Organization, 4(3), 115-128.

Bayraktaroglu, S. \& Kutanis, R.O. (2003). Transforming hotels into learning organizations: A new strategy for going global. Tourism Management, 24(2), 149-154.

Bremser, K., del Mar Alonso-Almeida, M., \& Gohlich, V. (2014). The Relevance of Organizational Characteristics for Crisis Planning. Business and Management Research, 3(4), 26-35.

Buhalis, D. \& Law, R. (2008). Progress in information technology and tourism management: 20 years on and 10 years after internet. The state of e-tourism research. Tourism Management, 24(4), 609-623.

Celemín, M.S. (2011). La captación de información a través de las nuevas tecnologías de la información y las comunicaciones en el sector hotelero. Revista electrónica CECIET, 1, 1-13.

Cronbach, L. (1951). Coefficient alpha and the internal structure of tests, Psycometrika, (16), 297-334.

Crossan, M., Lane, H., and White, R.E. (1999). Organizational Learning: From intuition to institution. Academy of Management Review, 24(3), 522-537.

Donate, M. (2007). Estrategias de conocimiento e innovación. Madrid: CES. Consejo Económico y Social.

Easterby-Smith, M., Crossan, M., and Nicolini, D. (2000). Organizational learning: Debates past, present and future. Journal of Management Studies, 37(6), 783-796.

Fraj, E., Matute, J., \& Melero, I. (2013). Learning and innovation as determininig factors in the development of proactive environmental management capability. Cuadernos de Economía y Dirección de la Empresa, 16(3), 180-193.

Fraj, E., Matute, J., \& Melero, I. (2015). Environmental strategies and organizational competitiveness in the hotel industry: The role of learning and innovation as determinants of environmental success. Tourism Management, 46, 30-42.

FRONTUR (2014). Nota de coyuntura de Frontur. Diciembre 2014. Avaible in: http://www.iet.tourspain.es/eses/estadisticas/frontur/paginas/default.aspx.

Furunes, T. (2005). Training paradox in the hotel industry. Scandinavian Journal of Hospitality and Tourism, 5(3), 231-248.

Gairín Sallán, J. (1997). La dirección en los procesos de aprendizaje colectivo. Alta Dirección, 191, enero-febrero.

Garau, J.B. \& Orfila-Sintes, F. (2008). Internet innovation for external relations in the Balearic hotel industry. Journal of Business and Industrial Marketing, 23(1), 70-80.

Garvin, D. (1993). Building a learning organization. Hardvard Business Review, 10(4), 803-813.
Ghaderi, Z., Mat Som, A. P., \& Wang, J. (2014). Organizational Learning in Tourism Crisis Management: An Experience From Malaysia. Journal of Travel \& Tourism Marketing, 31(5), 627-648.

Gjelsvik, M. (2002). Hotels and learning arenas. Scandinavian Journal of Hospitality and Tourism, 2(1), 31-48.

Huber, G.P (1991). Organizational learning: The contributing processes and the literatures. Organizational Science, 2(1), 88-115.

lebra Aizpurúa, L., Zerraga-Saldaña, P.E., \& Zerraga-Saldaña, A. (2011). Learning for sharing: Na empirical analysis of organizational learning and knowledge sharing. International Entrepreneurship Management Journal, 7, 509-518.

IECM (2012). Cuenta satélite del Turismo en la Región de Madrid. Avaible

http://www.madrid.org/iestadis/fijas/estructu/economicas/contabilid ad/estructucsattur.html.

Ingram, P. \& Baum, J.A.C. (2001). Inteorganizational learning and the dynamics of chain relationships. Multiunit Organization and Multimarket Strategy, 18, 109-139.

Jameson, S. M. (2000). Recruitment and training in small firms. Journal of European Industrial Training, 24(1), 43-49.

Jamal, T. \& Getz, D. (1995). Collaboration theory and community tourism planning. Annals of Tourism Research, 22(1), 186-204.

Kogut, B. \& Zander, U. (1992). Knowledge of the firm, combinative capabilities and replication of technology. Organization Science, 3(3), 383-397.

Kumar, I., Kumar, V. \& De Grosbois, D. (2008). Development of technological capability by cuban hospitality organizations. International Journal of Hospitality Management, 27(1), 12-22.

Kyriakidou, O. \& Gore, J. (2005). Learning by example. Benchmarking organizational culture in hospitality, tourism and leisure SMEs. An International Journal 12(3), 192-206.

Lim, S., Zegarra-Saldaña, A. \& Zegarra-Saldaña, P. (2011). Do market oriented firms adopt web 2.0 technologies? An empirical study in hospitality firms. International Entrepreneurship and Management Journal, 7, 465-477.

López Salazar, P. E., \& López Sánchez, J. A. (2001). Propuesta de un modelo conceptual de aprendizaje organizativo desde un enfoque cognoscitivo. II Encuentro Iberoamericano de Finanzas y Sistemas de Información, noviembre, 310-318.

Luthans, F. (1977). Introduction to Management: A contingency approach. New York: McGraw Hill.

March, J.G. (1991). Exploration and exploitation in organizational learning. Organizational Science, 2(1), 71-87.

Martín-Rojas, R., García-Morales, V.J. \& Mihi-Ramírez, A. (2014). Knowledge-based organization in tourism industry. Inzinerine Ekonomika-Engineering Economics, 25(1), 82-93.

Martínez, I. (2002). El aprendizaje en las organizaciones. Aplicación al sector agroalimentario. Tesis Doctoral. Universidad Politécnica de Cartagena.

Mazzocchi, M. (2008). Statistics for Marketing and Consumer Research London: SAGE Publications.

Mintzberg, H. (1984). La estructuración de las organizaciones. Barcelona: Ariel.

Morcillo, P., Rodríguez-Antón, J.M., Rubio, L., Esteban, C...., Soares, É. (2008). Las nuevas estructuras organizativas turísticas ante el reto del aprendizaje y la flexibilidad organizativa: una aplicación a las cadenas hoteleras españolas, mexicanas, brasileñas, chilenas y panameñas. Madrid: CEAL-UAM.

Nasution, H.N., Mavondo, F.T., Matanda, M. \& Oly-Ndubisi (2011). Entrepreneurship: Its relationship with market orientation and learning orientation and as antecedents to innovation and customer value. Industrial Marketing Management, 40, 336-345.

Nonaka, I. \& Takeuchi, H. (1995). The knowledge creating company: How Japanese companies creates the dynamics of innovation. New York: Oxford University Press.

Nonaka, I. \& Konno, N. (1998). The concept of "Ba": Building a foundation for knowledge creation. California Management Review, 40(3), 40-54.

Ordóñez de Pablo, P. (2002). Knowledge management and organizational learning: Typologies in the Spanish manufacturing industry from 19951999. Journal of Knowledge Management, 6(1), 52-62. 
Orfila-Sintes, F., Crespi-Cladera, R. \& Martínez-Ros, E. (2005). Innovation activity in the hotel industry. Omega, 37(2), 380-394.

Pham, N.T.T., Segers, M.S.R. \& Gijselaers, W.H. (2013). Effects of work environment on transfer of training: empirical evidence from Master of Business Administration Programs in Vietnam. International Journal of Training and Development, 17(1), 1-19.

Pablo Redondo, R. (2004). Las nuevas tecnologías aplicadas al sector turístico. Editorial Universitaria Ramón Areces.

Parte-Esteban, L., \& García, C. F. (2014). The influence of firm characteristics on earnings quality. International Journal of Hospitality Management, 42, 50-60.

Piccoli, G., O'Connor, P., Capiccioli, C. \& Álvarez, R. (2003). Customer relationship management: A driver for change in the structure of the US lodging industry. Cornell Hotel and Restaurant Administration Quartely, 44(4), 61-73.

Picón, E; Varela, J. \& Real, E. (2005). Clasificación y segmentación pos hoc mediante conglomerados. In Levy, J.P. and Varela, J. (Eds) Análisis Multivariable para las Ciencias Sociales, Prentice Hall, Madrid

Popper, M. \& Lipshitz, R. (2000). Organizational learning: Mechanisms, culture and feasibility. Management Learning, 31(2), 181-196.

Popescu, D., Chivu, I., Ciocârlan-Chitucea, A. \& Popescu, D.O. (2011). The development of touristic services: Through individual and organizational learning. Study case: Romania and Spain. Amfiteatru Economic, 13(5), 725-735.

Racherlaa, P. Hub, C. \& Martin Y. H. (2008). Exploring the Role of Innovative Technologies in Building a Knowledge-Based Destination. Current Issues in Tourism, 11(5), 407-428.

Redoli, J., Mompó, R., García-Díez, J. \& López-Coronado, M. (2008). A model for the assesment and development of Internet-based information and communication sevices in small and medium enterprizes. Technovation, 28(7), 424-435.

Rhodes, J., Lok, P., Yu-Yuan, R. \& Fang, S-Ch. (2008). An integrative model of organizational learning as social capital on effective knowledge transfer and perceived organizational performance. Journal of Workplace Learning, 20(4), 245-258.

Rodríguez-Antón, J.M. \& Alonso-Almeida, M.M. (2008). Dirección y Organización de Empresas Hoteleras. Madrid: Editorial Síntesis.

Rodríguez-Antón, J. M. \& Trujillo, C. (2007). ¿Las organizaciones son universidades que aprenden adecuadamente?. Universia Business Review, 15(Tercer Trimestre), 100-114.

Rodríguez-Antón, J. M, Alonso-Almeida, M. M., Celemín, M. \& Rubio. L. (2012). Use of different sustainability management systems in the hospitality industry. The case of Spanish hotels. Journal of Cleaner Production, 22(1), 76-84.

Ruhanen, L. (2008). Progressing the Sustainability Debate: A Knowledge Management Approach to Sustainable Tourism Planning. Current Issues in Tourism, 11(5), 429-455.

Ruíz-Molina, M.E, Gil-Saura, I. \& Moliner-Velázquez, B. (2011). Does technology make a difference? Evidence from Spanish hotels. Service Business, 5, 1-12.

Schilling, J. \& Kluge, A. (2008). Barriers to organizational learning: an integration of theory and research. International Journal of Management Reviews, 10(3), 1-24.

Scott, N. \& Ding, P. (2008). Management of Tourism Research Knowledge in Australia and China. Current Issues in Tourism, 11(6), 514-528.

Sooraksa, N. (2012). Using computer-based continuing professional education of training staff to develop small - and medium-sized enterprizes in Thailand. International Journal of Training and Development, 16(3), 235-242.

Sun P.Y.T. \& Anderson, M.H. (2008). An examination of the relationship between absorptive capacity and organizational learning, and a proposed integration. International Journal of Management Reviews, 12(2), 130-150.

Tajeddini, K. (2011). Customer orientation, learning orientation, and new service development: An empirical investigation of the Swiss hotel industry. Journal of Hospitality \& Tourism Research, 35(4), 437-468.

Teare, R. (2011). Learning at work: Practical steps to maximize the individual and organizational benefits. Worldwide Hospitality and Tourism Themes, 3(1), 14-29.

Thomas, R., \& Wood, E. (2015). The absorptive capacity of tourism organizations. Annals of Tourism Research, 54, 84-99.
WTTC (2015): Spain. How does Travel \& Tourism compare to other sectors? World Travel \& Tourism Council, Oxford Economics, London. Williams, M. (2001). A belief-focused process model of organizational learning. Journal of Management Studies, 38(1), 67-85.

Yang, J.T. (2004). Qualitative Knowledge capturing and organizational learning: Two case studies in Taiwan hotels. Tourism Management 25(4), 421- 428.

Yang, J.T. (2007). The impact of knowledge sharing on organizational learning and effectiveness. Journal of Knowledge Management, 11(2), 83-90.

Yang, J. T. (2008). Individual attitudes and organizational knowledge sharing. Tourism Management, 29(2), 345-353.

Yang, J.T., \& Wan, C.S. (2004). Advancing organizational effectiveness and knowledge management implementation. Tourism Management, 25(5), 593-601.

Zahra, S. A., and George, G. (2002). Absortive capacity: A review, reconceptualization and extension. Academy of Management Review, 27(2), 185-203.

\section{Annex 1. Hotel distribution by cluster and category}

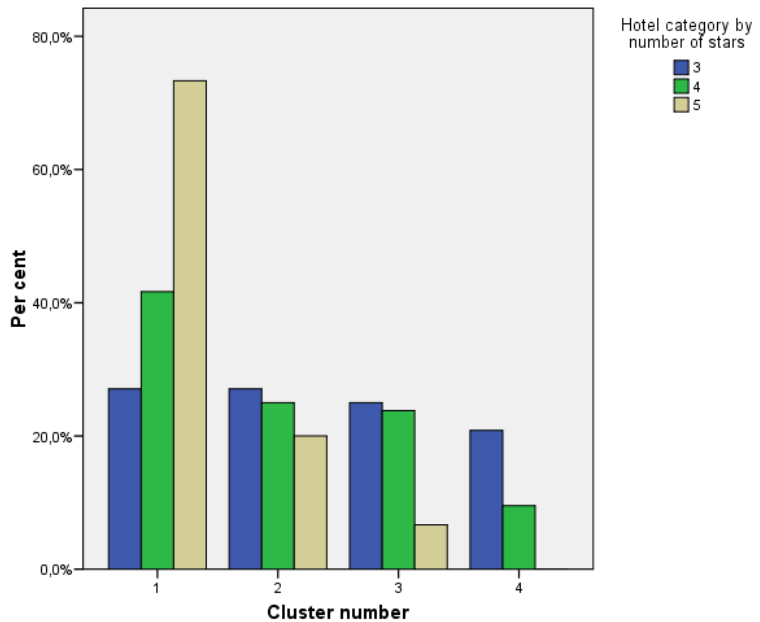

Annex 2. Hotel distribution by cluster and affiliation or otherwise with a hotel chain

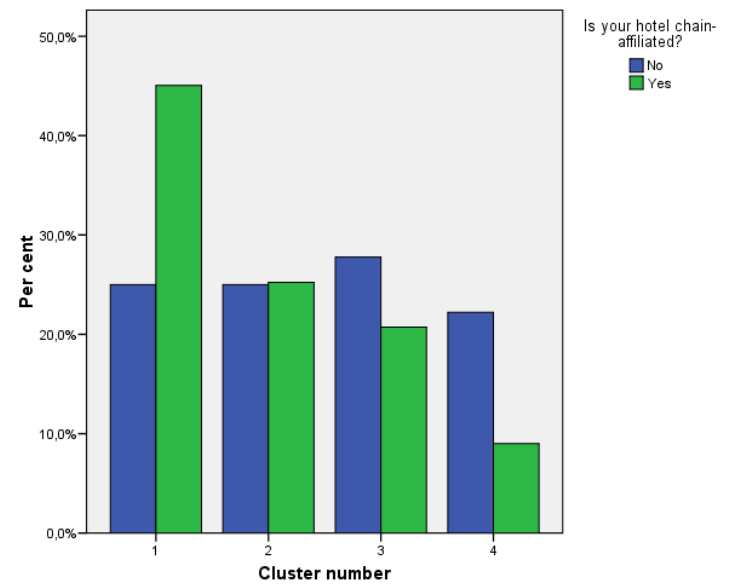

Article history

Submitted: 29.04.2015

Received in revised form: 29.08.2015

Accepted: 09.10.2015 